\title{
WHAT DOES DYNAMICS OF TOURISM MARKETING SHOW IN 12 DEVELOPING COUNTRIES?
}

\author{
Manuel Vanegas*1 (D) \\ ${ }^{1}$ Department of Applied Economics, University of Minnesota, USA
}

\begin{abstract}
This study is motivated by the idea to what extent tourism marketing investment contributes to tourism demand expansion. It searches for better estimation methods that can deal with the inter-temporal and cross-section correlation of the disturbances. The effect of omitting the tourism marketing variable, as evidenced by the drastic change in long and short-run elasticity values for all tourism demand models, has emerged clearly. There is a need for the national tourism institutions to have a clear, consistent, and sustained investment policy in tourism marketing activities with respect to enhanced effectiveness in allocating financial resources.
\end{abstract}

\author{
ARTICLE INFO \\ Received: February $4^{\text {th }}, 2021$ \\ Revised: October $5^{\text {th }}, 2021$ \\ Accepted: October $5^{\text {th }}, 2021$ \\ Online: November $25^{\text {th }}, 2021$ \\ *Correspondence: \\ Manuel Vanegas \\ E-mail: \\ vaneg001@umn.edu
}

Keywords: Tourism Marketing, 12 Developing Countries, Dynamic Panel, Elasticity Values, Omission of Tourism Marketing Variable.

JEL: Z33, C23,050

To cite this document: Vanegas, Manuel. (2021). What Does Dynamics of Tourism Marketing Show in 12 Developing Countries?. JDE (Journal of Developing Economies), Vol. 6(2), 201-222

\section{Introduction}

Over the last seven decades, the tourism sector panorama shows a tendency to increase tourism development activity in both tourist arrivals and receipts. Despite the economic crisis in the 1970s, 1980s and 2000s, the current economic slowdown, political turmoil, and health concerns related to the recent coronavirus 19 outbreak tourism sector has seen continued expansion in tourism development. Based on preliminary data reported by tourism destinations around the world to the United Nations World Tourism Organization-UNWTO, tourist arrivals stand at nearly 1.5 billion, with an average annual growth rate of almost $5 \%$, in 2019 (UNWTO, 2020).

On the other hand, tourism receipts are ranked number three in foreign exchange earnings behind chemicals and fuels exports and are growing well ahead of merchandize exports (UNWTO, 2019). Moreover, tourism growth at nearly $4 \%$ continues to outpace the world economy at almost $2.5 \%$. For nearly ten years in a row, tourism receipts have increased faster than merchandise exports worldwide, improving the balance of payments position, enhancing economic growth, and helping to reduce poverty in many developing countries (United Nations Conference on Trade and Development-UNCTAD, 2008, 2017; UNWTO, 2015; World Travel and Tourism Council-WTTC, 2020).

JDE (Journal of Developing Economies) p-ISSN: 2541-1012; e-ISSN: 2528-2018 
Suddenly in 2020, due to health concerns related to the Covid-19 outbreak, which completely transformed the global landscape, the tourism sector has seen a massive and continued decline in tourism development. Even with a resurgence of tourism demand in some parts of the world by the end of 2020, international tourism remains at a low level compared to pre-pandemic. Preliminary data collected and reported by the UNWTO (2021) shows an upper-end loss in tourist arrivals nearing the $78 \%$ mark. Under these scenarios, the impact of the loss of tourism demand in international travel could be translated into the loss of nearly US\$ 1.1 trillion in tourism receipts and almost 150 million in total (direct, indirect and induced) tourism jobs.

The assumption from which this study starts is that analysis of the determinants of the international tourism demand and estimating responses of their impact are very relevant to governments, international development institutions and the tourism business enterprises. The recent worldwide events in the 2000s, in 2010s and early 2020s, have forced tourism economics researchers, the international community, private tourism businesses, and the policymakers to remember that tourism marketing investments are pivotal for product positioning, image and/or branding enhancing, commercialization/selling, and promotion of a tourism destination.

The fact is, however, that very few studies have included the tourism marketing investment variable in the international tourism demand models (Brida \& Schubert, 2008; Crouch, 1994; Crouch et al., 1992; Papadopoulos \& Witt, 1985; Seetanah \& Sannassee, 2015; Song et al., 2010; Uysal \& Crompton, 1984; Witt \& Martin, 1995). In short, the research momentum of tourism marketing investment has grown slowly, and few researchers have worked at building the needed marketing, promotional and commercialization investments analytical and empirical bridges. This study is an example of work believed to be particularly relevant to present-day tourism developments in academia, developing, developed, least developed countries and the international development community as well as the private sector at large.

The objective of this study is threefold. First, the study test hypothesis suggests that there is a positive impact of tourism marketing investment which helps transform potential international tourism demand in real or effective tourism demand. Second, this study is related to the applicability of panel dynamics for East Africa, the Caribbean, Central America and South America. Third, the study searches for better estimation methods that allow dealing with the problem of inter-temporal and cross-section correlation of the disturbances.

The study attempts to answer the following research questions:

(a) As others have argued, is tourism marketing investment an additional determinant of the international tourism demand in the presence of the other standard income, price, and transportation cost variables, or are the effects of tourism marketing investment working through the other determinants or is absorbed by the error or the lagged dependent variable instead?

(b) Is there a predictive long-run empirical relationship between tourism development and marketing investment in the following four regions comprising 12 developing countries: Caribbean (Aruba, Barbados, Dominican Republic, and Jamaica), Central America (Costa Rica, El Salvador, and Guatemala), East Africa (Kenya, and Tanzania), and South America (Colombia, Ecuador, and Peru).? And if there is, to what extent does tourism development in developing countries, like the ones considered here, ceteris paribus, responds to changes in tourism marketing investment? 
The unbalanced panel for the period 1998-2018 is analyzed in a dynamic framework testing for the impact of tourism marketing investment on tourism development. To estimate the coefficients of the dynamic panel, the selected number of models available for analyzing international tourism demand are applied: The General Method of Moments (GMM) estimation method suggested by Arellano \& Bond (1991); the Balestra \& Nerlove (1966) procedure, and the Fully Modified Ordinary Least Square (Phillis \& Hansen, 1990 \& Pedroni, 2000). The Ordinary Least Square pooled estimator (OLS) results are reported for comparison reasons only. A computation of errors is added to highlight the model's susceptibility to problems related to underlying model assumptions.

The contribution of this study is fivefold. First, it represents the first application of panel dynamic analysis methodology on the extent to which tourism marketing investment relates to international tourism demand in twelve selected developing countries.

Second, this study enhances the literature. It extends and adds new empirical evidence to the literature by investigating if tourism marketing investment is an additional determinant of tourism development in the presence of the other standard determinants.

Third, this study marks significantly advances over past research. It undertakes an indepth analysis of the impact of the tourism marketing variable in terms of elasticity estimates by testing the extent of bias due to the omission of the tourism marketing variables.

Fourth, this study uses official or national datasets only. It provides modelling and quantitative reference material to policymakers, tourism private sector investors, academia, international development institutions, and other researchers who might be interested in conducting research in similar or related areas of this study.

Fifth, it provides valuable guidance for policymakers and the private sector engaged in integrated tourism development and marketing policy formulation and/or strategies in other developing countries with similar tourism development processes and components like the ones considered here.

\section{Market Trends Analysis}

For the whole panel, the UNWTO and national tourism offices' estimates reveal that Africa increased by nearly $6 \%$ and by nearly $2 \%$ in tourism arrivals and receipts, respectively, in 2019, with strong performance by Kenya and Uganda. The America's tourism arrivals increased by nearly $2 \%$. However, tourism receipts remained unchanged. Barbados, Dominican Republic and Jamaica showed strong performance in the Caribbean; Costa Rica in Central America: and Colombia, Ecuador and Perú in South America (UNWTO, 2020; WTTC, 2020).

As shown in Table 1, the tourism sector accounts, on average, for nearly $16.80 \%$ of the twelve countries' gross domestic product, for nearly $16.73 \%$ of total jobs (nearly 7.4 million jobs) and for nearly $19.89 \%$ of total exports, in 2019. On average, among those with the highest gross domestic product (40.72\%), jobs (41.38\%) and tourism exports $(39.28 \%)$ components belong to the Caribbean. The labour-intensive nature of tourism development creates echo-links with many other economic sectors, which position tourism development as a pivotal contributor to enhancing economic growth, reducing poverty, and formulating development strategies (Croes, 2014; Fayissa et al.; 2008; UNCTAD, 2017; UNWTO, 2019; Vanegas, 2012; Vanegas et al., 2015).

It is relevant to note that, at a time when developing countries are pursuing enhanced 
economic growth, increased generation of foreign exchange earnings, creation of more jobs and improved performance in poverty reduction, all of them see the potential of tourism to boost their quest for a consistent and steady structural transformation (Ajagunna et al., 2017; Brida et al., 2016; Croes \& Rivera, 2017; Croes \& Vanegas, 2008; Fayissa et al., 2011; Okello \& Novelli, 2014; Saner et al., 2015; Signé \& Johnson, 2018).

Table 1: The Economic Impact of Tourism, 2019

\begin{tabular}{lccc}
\hline Country Group & Gross Domestic Product $^{2}$ & Employment & Total Exports $^{\mathbf{3}}$ \\
\hline Full Panel & 16.80 & 16.73 & 19.89 \\
\hline East Africa & 9.43 & 8.37 & 16.92 \\
\hline Caribbean & 40.72 & 41.38 & 39.28 \\
\hline Central America & 10.18 & 10.01 & 12.04 \\
\hline South America & 6.85 & 7.14 & 11.33 \\
\hline
\end{tabular}

Source: Constructed by the author using the latest official information provided by their respective: Bureau of Statistics, Central Banks Balance of Payment, National Accounts and Tourism Entities of the twelve countries considered in this study. ${ }^{1}$ Subject to revision; ${ }^{2}$ A broader measure of economic activity was used, such as the tourism's overall economic impact (direct, indirect, induced), $2015=100 ;{ }^{3}$ Current value; ${ }^{4}$ Aruba, Barbados and Jamaica belong to the top 25 Caribbean countries in terms of tourism contribution to the total economic activity, foreign exchange earnings and employment.

As related to country groups, tourist arrivals from Canada, the United States, the United Kingdom, and regional border countries to the Caribbean, Central America, East Africa, and South America have dominated total tourist arrivals. In 2019, due to economic recovery, followed the positive trend of previous years, East Africa and South American countries reported the largest positive results, although a few faced health and safety incidents, either in their country or in their region.

As shown in Table 2, overall tourist arrivals growth increased by an accumulative yearly average of nearly $4.94 \%$ or nearly 1.15 times greater than the world average during the period 2000-2019. Except for East Africa and the Caribbean, it was the seventh and the sixth consecutive year of above-average growth in international tourism arrivals for Central American and South American countries. However, the average growth rate in tourist arrivals was not homogenous either through the period or from the tourism source markets. The most significant increase was for South America with nearly 5.18\% during the period 2000-2019.

Table 2 also reveal that South America led estimated tourist arrivals growth with a nearly $10.32 \%$ increase, or nearly 5.1 and 2.6 times than the Americas and the World, respectively. It was followed by Central America, with an estimated growth rate of nearly $7.42 \%$, in 2019. For some tourism destinations, the decrease in the number of tourist arrivals could be interpreted as the impact of the economic crisis and/or health concerns. On the other hand, in many developing countries included in the panel, tourism receipts rank as the first export economic sector. Overall tourism receipts growth in real terms (accounted for exchange rates and inflation for comparability) increased by an estimated average of nearly $5.59 \%$ during the period 2000-2019, or nearly 2.1 times greater than the world average (preliminary information from the twelve countries' Central Banks; UNWTO, 2020; WTTC, 2020).

With respect to marketing investment activities, national tourism agencies take tourism development activities to increase tourist arrivals by stepping up tourism marketing investment efforts in tourism origin markets. All of them organize, among others, information (awareness), commercialization networks, image enhancing, and advertising campaigns, as 
well as promoting other tourism-related initiatives. This is the result of increased and fierce competition from tourism destinations around the world (Brida \& Schubert, 2008; Buhalis, 2005; Signé \& Johnson, 2018; Vanegas, 2013b, 2014).

Table 2: Tourism Developments Yearly Average Growth Rates²000-2019

\begin{tabular}{|c|c|c|c|c|c|}
\hline Period/Year & Full Panel & East Africa & The Caribbean & Central America & South America \\
\hline \multicolumn{6}{|l|}{ Tourist Arrivals } \\
\hline $2000-2019$ & 4.94 & 5.12 & 4.14 & 4.54 & 5.18 \\
\hline $2000-2010$ & 5.65 & 4.87 & 3.86 & 6.40 & 6.11 \\
\hline 2010-2019 & 5.87 & 6.63 & 4.32 & 4.42 & 5.71 \\
\hline $2019^{2}$ & 5.62 & 7.04 & 3.72 & 7.42 & 10.32 \\
\hline \multicolumn{6}{|l|}{ Tourism Receipts $^{3}$} \\
\hline $2000-2019$ & 5.59 & 5.53 & 4.68 & 4.90 & 5.42 \\
\hline $2000-2010$ & 5.92 & 5.47 & 6.04 & 6.76 & 6.19 \\
\hline 2010-2019 & 6.70 & 6.76 & 6.98 & 5.08 & 5.63 \\
\hline $2019^{2}$ & 7.69 & 13.12 & 3.91 & 7.14 & 8.34 \\
\hline \multicolumn{6}{|c|}{ Marketing Spending ${ }^{3}$} \\
\hline 2000-2019 & 1.32 & 1.02 & 2.18 & 1.92 & 2.94 \\
\hline $2000-2010$ & 1.62 & 0.87 & 2.21 & 1.98 & 2.47 \\
\hline 2010-2019 & 2.03 & 1.08 & 2.66 & 2.22 & 3.03 \\
\hline $2019^{2}$ & 2.87 & 1.74 & 2.73 & 2.36 & 3.14 \\
\hline
\end{tabular}

Source: Author's calculations using the official tourism institutions' statistical databases included in the panel. Tourism receipts are from the statistical databases of each country's Central Bank's Balance of Payments. ${ }^{1}$ The growth rate is calculated using the following exponential equation: $\log Y=\log \alpha+\beta$ TIME where $\beta$ multiplied by 100 provides the growth rate value. ${ }^{2}$ Preliminary as expressed by the official authorities at the time of writing this study. ${ }^{3}$ In real terms $(2015=100)$.

As shown in Table 2, tourism marketing investments, for the full panel, in real terms (2015 $=100)$, increased at an annual average growth rate of nearly $1.32 \%$ per year during the period 2000-2019, but results vary across country groups. The rate of growth in tourism marketing investments was not homogenous either through the period or from the tourism source markets. The most significant increase was for South America, with nearly $2.94 \%$ per year, and the least significant was East Africa, with nearly $1.02 \%$ per year during the same period. Preliminary estimates reveal that South America led marketing investment growth with nearly $3.14 \%$ increase in tourist marketing investments in 2019, followed by the Caribbean with nearly 2.73 percent.

It is relevant to note that most of tourism's work plans, reports, and national tourism policy documents have at least five focal points common to all of them: (1) targeted tourism marketing activities on driving tourist arrivals and tourism receipts; (2) protection and enhancement of tourism image and brand name; (3) strengthened tourism sales support through partnership with, among others, airlines, hotel investors, and communication groups; (4) increased use of new information, technology and social media; and (5) tourism product development and positioning through tourism meetings, incentives, conferences and events (Africa Development Bank-AFDB, 2015, 2018; Association of Caribbean States, 2017; Christie et al., 2014; Government of the Republic of Kenya, 2013; Okello \& Novelli, 2014; Hartwell, 2018; Signé \& Johnson, 2018; The United Republic of Tanzania, 2002; Tourism Research Institute, 2018; UNCTAD, 2017). 


\section{Literature Review}

\section{Tourism Marketing and its Conceptual Insights}

There is limited but interesting literature as related to the study of tourism marketing investment and its interactions with other variables like income, price, and transportation cost. The relatively majority of the existing empirical studies, in evaluating the role of tourism marketing investment and/or promotional spending, and/or advertising spending has involved developed countries and is very scarce (Donohoe, 2012; Eagle et al., 2016; Hinch et al., 2016, Vanegas, 2013a, among others).

Despite that tourism marketing investment is pivotal for informing, promoting and selling a tourism destination. Estimates from the available empirical evidence show that only nearly $7.4 \%$ (nearly 33 studies) out of nearly 450 studies surveyed have included this variable in the international tourism demand models (Ahmed, 2015, 70 studies; Crouch, 1994, 85 studies; Crouch \& Shaw, 1991, 58 studies; Lim, 1997, 100 studies; Song \& Li, 2008, 121 studies; Vanegas, 2013b \& 2014a, 6 and 10 studies, respectively).

The current state-of-affairs has occurred despite that developing, developed, least developed, socialists, and democratic countries, have been injecting relatively a vast amount of economic and financial resources from their fiscal budgets on marketing activities. In a descriptive manner, however, without the rigorous and appropriate evidence being presented, it has been argued that this is due to data availability and/or the difficult of gathering reliable and relevant data (Crouch, 1994, p. 15; Crouch et al., 1992, p. 199; Papadopoulos \& Witt, 1985, p. 690; Seetanah, 2010, pp. 3-5; Seetanah \& Sannassee, 2015, pp. 203-206; Song et al., 2010, p. 70; Uysal \& Crompton, 1984, p. 58; Vanegas, 2014, p.3; Witt \& Martin, 1987, pp. 3334).

Therefore, under the international tourism demand paradigm, there is no other way: the buyer, or the consumer unit, or the potential tourist must travel to the chosen tourism destination, the producer. In this scenario, the tourism development sector must use tourism marketing investments as the primary tool in implementing and managing tourism originating markets for awareness, commercialization/sales, competitiveness, and expansion. It all means that tourism marketing investment plays a pivotal role and is a crucial tool in developing tourism by skillfully presenting the tourism destinations' distinctively main tourism products and services (Bonnet, 1982; Buhalis, 2005; Donohoe, 2012; Esu \& Ebitu, 2010; Jamal \& Camargo, 2014; Hinch et al, 2016; Liu \& Chou, 2016; March, 1994, among others).

\section{Relatively Meager Empirical Evidence}

Clarke (1978, p. 38), in his Ph.D thesis on Tourism Demand Analysis for the Caribbean Island of Barbados using national/official information, which included a promotion expenditure variable, produced the most comprehensive tourism demand study examining this independent variable. He used four different model specifications with various types of accommodations: luxury and class A hotels, class B hotels, and under guest houses other types of accommodations such as guest houses, villas, and condominiums. He considered the element of seasonality in summer and winter. He documented that increasing promotion expenditures enhances tourism demand for all considered countries. His results indicated that, on average, a promotion elasticity value of nearly 0.55 for winter (lowest nearly 0.15 for Trinidad and Tobago-class A hotels, the highest nearly 0.80 for Canada-luxury hotels). The average for summer was nearly 0.53 (lowest nearly 0.13 for United Kingdom-class A hotels, highest nearly 0.93 for Canada-guest houses). 
Uysal \& Crompton (1984), in their tourism demand for Turkey from eleven (11) origin markets, the authors reported tourism promotion efforts to be significant on six (6) out of the eleven (11) countries studied and that their elasticity values ranging from the lowest of nearly 0.02 for France to the highest of nearly 0.6 for Spain.

Crouch et al. (1992), Divisekera \& Kulendran (2006), Kulendran \& Divisekera (2007), and Kulendran \& Dwyer (2009), in their tourism demand for Australia from its main markets, the authors revealed that marketing expenditures have positive effects on tourism demands with elasticities ranging from the lowest of nearly 0.022 for Japan to the highest of nearly 0.37 for Asia for an overall average of nearly 0.12 .

Vanegas (2013b, 2014) studied both the dynamics of tourism demand relationship between tourist arrivals/tourism receipts, marketing promotion spending, relative price, transportation cost, and income for Aruba and its main markets. The results revealed that marketing spending positively affects tourist arrivals with elasticity values ranging from nearly 0.28 to nearly 0.45 . The analysis on the United States market revealed an elasticity value of nearly 0.47 for the period 2000-2013 versus an elasticity value of 0.38 for 2010-2013. On the other hand, when tourism receipts were considered as the dependent variable the elasticity values were positive, significant, but relatively lower.

Both, Seetanah (2010) and Seetanah, \& Sannassee (2015), measured tourism promotional expenditure by the amount of money allocated to the Mauritius Tourism Promotion Agency. Their results reported that tourism promotional efforts contributed positively to tourist arrivals in the long and short-run, with elasticity values of nearly 0.16 and nearly 0.14 , respectively. Recently, Seetanah et al. (2019), using an interactive factor analyzed the dual impact of the interplay between air liberalization and marketing promotion efforts for Mauritius. Their findings point to the positive and significant impact of the interplay between air access liberalization and marketing promotion efforts in attracting more tourists.

Other tourism marketing studies have discussed its theory, practice and methodologies. Relatively, these studies have validated the positive role of tourism marketing investment (Correia \& Kozak, 2010; Dae-Young et al., 2005; Fallon \& Schofield, 2006; Mazanec, 2005; Scott et al., 2009).

\section{Data and Research Methods}

\section{Model Framework}

A common characteristic of tourism studies similar to this kind is that the dynamic relationship, as applied to panel data, between dependent and independent variables is captured by the value of the coefficient of the lagged dependent variable (Baltagi, 2013).

The international tourism demand function may be expressed as in equation (1):

$$
T O U a_{i t}=F\left(I N C_{i t}, P_{i t}, T C_{i t}, M A_{i t}, T O U a_{i t-1}, D U M M I E S\right)
$$

All these variables are logarithmic-transformed and the corresponding dynamic panel data model is formed as in equation (2):

$$
\begin{gathered}
\text { LnTOUa }_{i t}=\pi+B_{1} \text { LnINC }_{i t}+B_{2} L n P_{i t}+B_{3} L n T C_{i t}+B_{4} L n M A_{i t}+b_{5} L n T O U a_{i, t-1}+ \\
B_{6} D 1+b_{7} D 2+b_{8} D 3+\alpha_{i}+\varepsilon_{i t}
\end{gathered}
$$

Where total tourist arrivals TOUa $\mathrm{itt}$ is the proxy for international tourism demand from 
the tourism source market (i) to the tourism destination in year $(\mathrm{t})$; INC $\mathrm{I}_{\text {it }}$ represents real income measured by the real gross domestic product $(2015=100)$ of individual tourism source country (i) in year (t).

Three of the most cumbersome parts of any international tourism demand, pertains to deciding on an appropriate measure of tourism price, cost of travel, and tourism marketing investment variables. Why? Simply, because in terms of data availability, it constitutes a most precarious case and they are relatively difficult to measure.

With respect to the price variable, basically, the tourist confronts two prices, the price of living in the destination, and the price of travel to the tourism destination (Witt \& Witt, 1995). It would be suitable, however, to develop and use a tourism price index, comprising the goods and services bought by tourists at the tourism destination. Regrettably, this kind of tourism price index is not available (Artus, 1970; Croes \& Vanegas, 2005; Jud \& Joseph, 1974; Kliman, 1981; Seetanah \& Sannassee, 2015). In this study, the relative price index $P_{i t}$ represents a weighting structure based on the origin market shares merged with the exchange rate. For East Africa: Canada, the United States and the United Kingdom; for Central America: Canada and the United States; for the Caribbean: Canada, the United States and the United Kingdom; and for South America: Canada, the United States, and the United Kingdom.

These estimates purely assumed that the tourism goods and services bought by tourists are equivalent to those bought in their origin countries. In short, it allows substitution between domestic tourism of the countries under consideration and international tourism destinations. Despite these qualifications, however, satisfactory and coherent time series data were developed or obtained.

The price of crude oil in constant $(2015=100)$ United States dollars $\left(\mathrm{TC}_{\mathrm{it}}\right)$ is used as a proxy for the travel cost variable. $\mathrm{TC}_{\text {it }}$ represents the cost of travel between the origin and destination countries. The defined transport variable is expected to be a good proxy reflecting changes in fuel and airfare prices. In addition, this approach reduces the variations due to distances, the different modes of travel used by tourists (air, car, coach, and so on) from the origin countries, and the different prices for different categories of fuel used (regular and premium gasoline, diesel and so on).

The variable $\mathrm{MA}_{\text {it }}$ represents tourism marketing investment in promotion. It is computed from the national government budgets and reconciled with the corresponding tourism ministries and tourism institutes. Tourism organizations' managerial tasks, personal, private sector tourism marketing investments (airlines, tour operators, travel agents, individual hotels, among others) and non-industry contributions, however, are not accounted for in the $\mathrm{MA}_{\mathrm{it}}$ variable. Thus, the tourism marketing investment in the promotion of the tourism ministries and/or tourism institutes are but part of the total investments in a promotion.

Three dummy variables were used to capture the impact of unexpected events: (D1) measuring the terrorist attacks on the United States in 2001 and its aftermath; (D2) measuring the global economic crisis in 2008-2011; and (D3) measuring the 2014-2015 Ebola outbreak scare in West Africa, which negatively affected tourism development in Kenya and Tanzania and all over Africa. The dummy variables take the value of 1 in the year of the occurrence of the special event and 0 otherwise.

The GMM representation can be formulated as in equation (3):

$$
\begin{gathered}
\Delta L n T O U a_{i t}=\alpha_{0}+\alpha_{1} \Delta L n I N C_{i t}+\alpha_{2} \Delta L n P_{i t}+\alpha_{3} \Delta L n T C_{i t}+\alpha_{4} \Delta L n M A_{i t}+\alpha_{5} \Delta L n- \\
T O U a_{i, t-1}+\alpha_{6} D 1+\alpha_{7} D 2+\alpha_{8} D 3+\xi_{i t}
\end{gathered}
$$




\section{Concerns on Data and Source}

While many of the countries, globally, have well-organized data collection frameworks, and make data available to the public through regular official publications on their respective websites, others have relatively less macroeconomic and tourism statistics available. To be more specifics, however, collecting, monitoring and reporting on the levels, patterns and trends of tourism marketing and promotional investments have not been a standard part of governments and multilateral institutions' statistical programs design and assessment.

In this context, regional and multilateral institutions (e.g., Caribbean Tourism Organization, the United Nations World Tourism Organization and the World Bank, among others) have failed to develop a national or official template for regular reporting, among others, concepts, definitions, data sets and instruments related to tourism marketing and promotional investments. In short, little attention has been paid to the fact that the worldwide tourism sector does not have reliable and consistent measures of tourism marketing investments suitable for analysis and inter-country comparisons.

The analysis in this study, however, for the first time, has used estimates for the twelve developing countries considered, which are consistent with their national accounts, central banks, bureau of statistics, tourism entities' perpetual databases and ministries of finance or government budgets. It makes them comparable over time and across countries. All macroeconomics databases comply with the common international definitions set up by the United Nations (statistical Division), the United Nations World Tourism Organization, and the International Monetary Fund.

The data were based solely on the information that was available to this study at the time of its development. It was kindly supplied by the different national entities of the twelve countries considered in this study. The data for the origin countries of Canada, the United Kingdom and the United States were obtained from the Ministry of Industry Statistics (Canada), Office for National Statistics (United Kingdom), Bureau of Labor Statistics, and Bureau of Economic Analysis (United States).To achieve the best possible combination of consistency, comparability, reliability and completeness, all the data were cross-checked, where possible: via physical visits and telephone guided interviews with government officials to further validate quantitative and qualitative data.

The study computed a consistent set of estimates in constant 2015 US dollars. For example, for the income variable, the process included, first rebasing each country's gross domestic product in constant currency to the common base year and second conversion of the estimates obtained into US dollars. The first step was necessitated by the fact that countries use different base years for their calculations of constant price series in their national accounts.

After discarded observations due to inconsistency, lack of agreement about reconciling procedures, calibration and comparability issues, the analysis ended up with an unbalanced panel containing a total of 203 observations: 29 observations for East Africa: Kenya for the period 2003-2017 and Tanzania for the period 2004-2017; 79 observations for the Caribbean: Aruba for the period 2000-2018, Barbados for the period 1998-2017, the Dominican Republic for the period 1998-2018 and Jamaica for the period 1999-2017; 50 observations for Central America: Costa Rica for the period 1999-2017, El Salvador for the period 2004-2017, and Guatemala for the period 2000-2016; and 45 observations for South America: Colombia for the period 2001-2016, Ecuador for the period 2003-2015 and Perú for the period 2000-2015. 
Table 3 shows the descriptive statistics of the data in logarithmic transformation, which aims to stabilize their variances. Data dispersion measured by the coefficient of variation, as percentage around the mean, shows relatively low volatility between variables of nearly $4.6 \%$ (tourist arrivals) and $15.8 \%$ (travel cost).

\section{Finding and Discussion}

The study utilized the General Methods of Moments estimator procedure (Arellano \& Bond, 1991) to estimate the dynamics of international tourism demand for the regions of East Africa, the Caribbean, Central America, and South America from their main origin markets.

Table 3: Descriptive Statistics of Variables

\begin{tabular}{cccccc}
\hline Statistics & Ln TOUa & Ln INC & Ln P & Ln TC & Ln MA \\
\hline Maximum & 17.6820 & 13.1476 & 2.8456 & 4.6652 & 3.5812 \\
\hline Mean & 14.0903 & 11.1412 & 2.2733 & 3.8127 & 2.0367 \\
\hline Median & 14.0168 & 11.0639 & 2.1981 & 3.9216 & 2.0438 \\
\hline Minimum & 12.9613 & 7.3043 & 1.6579 & 2.6579 & 2.4191 \\
\hline Std. Dev. & 0.6484 & 0.8591 & 0.1857 & 0.6074 & 0.2318 \\
\hline Kurtosis & 3.0260 & -0.0618 & 0.2217 & -1.1536 & -0.0938 \\
\hline Skewness & 1.0018 & 1.3271 & 2.3349 & -0.3457 & 1.5329 \\
\hline CV & 0.0458 & 0.0771 & 0.0816 & 0.1583 & 0.1139 \\
\hline
\end{tabular}

Source: Author's calculations from the logarithm of the official statistical databases of the countries' central banks, statistical institutions (or bureaus) and tourism offices.

${ }^{1}$ Coefficient of variation $=$ Standard. Deviation/Mean*100.

For the purpose of robustness in the estimation of the lagged dependent variable and sensitivity in the question of the impact of the tourism marketing variable in a dynamic panel model, two more econometric procedures were used: the Balestra \& Nerlove (1966) estimator and the Fully Modified Ordinary Least Squares (Phillips \& Hansen, 1990 in the time series context; Pedroni, 2000 in the panel context-FMOLS). For comparison purposes, initially, the conventional pooled ordinary least square estimation method is applied (OLS).

\section{Full Sample Pooled Findings}

In the presence of a dynamic relationship, the Im et al. (2003) panel unit root test was applied on the dependent and independent variables to establish their panel unit root properties (See Table 4). Using the pooled version means that the assumption that treats the slope coefficients as common value has been maintained. However, this restricted assumption is removed for the applicability of the pooled estimators in the context of individual country-group analysis. This estimation strategy allows the opportunity to compare the cross-country distribution of the slope coefficients.

The results of the full panel OLS, the B-N, the FMOLS and the GMM estimates are given in Table 5 columns 2, 3, 4 and 5. Focusing on the GMM results and the different tests of model validity, Table 5 , column 5 shows the following interesting results. The impact of MA is positive and statistically significant at the $1 \%$ confidence level and its short-run elasticity value is 0.43 (inelastic). On the other hand, its long-run elasticity value is nearly 0.98 . In the short and longrun, on average, a $1 \%$ increase in tourism marketing investment leads to nearly $0.43 \%$ and $0.98 \%$ increase in tourist arrivals, respectively. 
For all versions of estimations these results, accounting for small differences, are similar with estimates by Clarke (1978) and Vanegas (2013b, 2014). These findings, however, are relatively higher to the estimates by Barry \& O'Hagan (1972), Crouch et al. (1992), Papadopoulos \& Witt (1985), Seetanah et al. (2010), Seetanah \& Sannassee (2015), Seetanah et al. (2019), and Uysal \& Crompton (1984)-exception of Spain. Some of the differences between the other studies and this study is that some of the other studies' estimates are from country to country, used different methodologies and the data sources and periods are different.

Table 4: Panel Unit Root ${ }^{1}$

\begin{tabular}{llllll}
\hline Region & LogINC & LogP & LogTC & LogMA & LogTOU \\
\hline Africa & & & & \\
\hline Series in levels & -1.8682 & -1.6473 & -2.1146 & -2.2613 & -0.9337 \\
\hline Series in differences & -4.3068 & -3.7266 & -3.8864 & -7.4118 & -3.3604 \\
\hline The Caribbean & & & & -2.3618 \\
\hline Series in levels & -1.6411 & -1.5340 & -2.4408 & -1.5892 & -6.5392 \\
\hline Series in differences & -4.6695 & -3.6252 & -6.5270 & -3.6706 & -2.1643 \\
\hline Central America & & & & -1.9379 & -5.8172 \\
\hline Series in levels & -1.7561 & -1.5644 & -2.8589 & -3.5126 & \\
\hline Series in differences & -6.0395 & -3.5763 & -4.3788 & & -1.2901 \\
\hline South America & & & & -1.3428 & -4.1162 \\
\hline Series in levels & -1.3029 & -1.5443 & -2.4634 & -5.2322 & \\
\hline Series in differences & -4.5562 & -3.7620 & -7.4291 & & \\
\hline
\end{tabular}

${ }^{1}$ All tests were conducted with intercepts and linear trends in levels and first differences.

The long-run income elasticity value is nearly 3.75 (elastic-typical of a luxury good). It means that a $1 \%$ increase in income leads, on average, to nearly $3.75 \%$ increase in tourism arrivals for the full sample. The short-run income elasticity is nearly 1.64 (elastic), as expected, smaller than its long-run counterpart. These results suggest that the economic condition of the country of origin is the most important factor in determining tourism demand. Policies aimed to closely monitor the economic developments in the major source markets could pay dividends to reduce income shocks.

Turning to price, the long-run price elasticity value is nearly -1.19. On the other hand, its short-run price elasticity value is nearly -0.52 , or inelastic. As expected, tourism demands are more responsive to relative prices in the long-run than in the short-run. On average, a $1 \%$ increase in relative prices leads to nearly $1.19 \%$ decrease in tourist arrivals, in the long run. This result corresponds to the estimates by Garín-Muñoz (2007), Seetanah \& Sannassee (2015), Uysal \& Crompton (1984), and Vanegas (2013a \& 2018). The results indicate that in the long-run, care must be taken by the tourism sector in order to maintain or improve the competitiveness of its products and services.

The transportation cost elasticity values vary from nearly -0.48 in the short-run to nearly -1.10 in the long-run. As expected, international tourism demands are more responsive to transportation cost in the long-run than in the short-run. On average, a $1 \%$ increase in transportation cost leads to nearly $1.10 \%$ decrease in tourist arrivals, in the long-run. These results are similar to the estimates in Seetanah (2010), Uysal \& Crompton (1984), and Vanegas (2018). 
Table 5: Full Panel Pooled Coefficient Estimates ${ }^{1}$

\begin{tabular}{|c|c|c|c|c|}
\hline Variable & OLS Estimates ${ }^{2}$ & B-N Estimates & FMOLS Estimates & GMM Estimates ${ }^{3}$ \\
\hline \multicolumn{5}{|l|}{ Short-run } \\
\hline \multirow[t]{2}{*}{ LnINC } & $3.13^{* * *}$ & $1.68^{* * *}$ & $1.84^{* * *}$ & $1.64^{* * *}$ \\
\hline & (3.671) & (4.963) & $(4.426)$ & $(4.566)$ \\
\hline \multirow[t]{2}{*}{$\operatorname{LnP}$} & $-1.25^{* *}$ & $-0.68^{* * *}$ & $-0.61^{* * *}$ & $-0.52^{* * *}$ \\
\hline & $(-1.983)$ & $(-4.161)$ & $(-3.092)$ & $(-3.814)$ \\
\hline \multirow[t]{2}{*}{ LnTC } & $-1.12^{* *}$ & $-0.47^{* *}$ & $-0.57^{* * *}$ & $-0.48^{* * *}$ \\
\hline & $(-2.181)$ & $(-2.118)$ & $(-2.283)$ & $(-2.889)$ \\
\hline \multirow[t]{2}{*}{ LnMA } & $0.76^{* *}$ & $0.46^{* * *}$ & $0.47^{* * *}$ & $0.43^{* * *}$ \\
\hline & $(2.343)$ & $(4.934)$ & $(3.147)$ & $(3.637)$ \\
\hline \multirow[t]{2}{*}{ D1 } & $-0.26^{* * *}$ & $-0.31^{* * *}$ & $-0.29 * *$ & $-0.38^{* * *}$ \\
\hline & $(-3.024)$ & $(-2.938)$ & $(-2.038)$ & $(-3.911)$ \\
\hline \multirow[t]{2}{*}{ D2 } & $-0.34^{* * *}$ & $-0.38^{* * *}$ & $-0.35^{* * *}$ & $-0.36^{* * *}$ \\
\hline & $(-4.397)$ & $(-3.661)$ & $(-4.609)$ & $(-6.180)$ \\
\hline \multirow[t]{2}{*}{ D3 } & $-0.14^{*}$ & - & - & - \\
\hline & $(-1.792)$ & - & - & - \\
\hline \multirow[t]{2}{*}{ LnTOUa $_{t-1}$} & - & $0.4823^{* * *}$ & $0.4990^{* * *}$ & $0.5621^{* * *}$ \\
\hline & - & $(5.076)$ & $(6.263)$ & $(6.971)$ \\
\hline $\mathrm{R}^{2}$ adjusted & 0.587 & 0.689 & 0.713 & 0.706 \\
\hline F-statistics & 7.142 & 8.039 & 8.632 & 9.312 \\
\hline Sargan test ${ }^{4}$ & - & - & - & 39.621 \\
\hline $\operatorname{Ar}^{5}$ & - & - & - & -2.152 \\
\hline $\mathrm{Ar} 2^{5}$ & - & - & - & -1.015 \\
\hline \multicolumn{5}{|l|}{ Long-run } \\
\hline LnINC & 3.13 & 3.25 & 3.67 & 3.75 \\
\hline $\operatorname{LnP}$ & -1.25 & -1.31 & -1.22 & -1.19 \\
\hline LnTC & -1.12 & -0.91 & -1.14 & -1.10 \\
\hline LnMA & 0.76 & 0.89 & 0.94 & 0.98 \\
\hline Countries & 12 & 12 & 12 & 12 \\
\hline Observations & 203 & 203 & 203 & 203 \\
\hline
\end{tabular}

${ }^{1}$ Stata version $13 .{ }^{2}$ Long-run coefficients. ${ }^{3}$ One step GMM estimates. The one-step robust estimates were similar. All the estimates were obtained using the instrument LnTOUa lagged up to two periods to reduce finite sample biases resulting from having too many instruments. ${ }^{4}$ Validity of the Ho: over-identifying restrictions. It was based in the two-step estimator. ${ }^{5}$ The tests do not detect any serial correlation problem in the residuals. Estimates would be inconsistent if the Ho: of no second-order serial correlation is rejected.

In the GMM specification, the significant, positive, and less than unity $(0.4379)$ shortterm impact of the lagged tourist arrivals indicate both that the adjustment process plays a non-negligible role, and that a period of more than a year is required for tourists to adjust their travel decisions in response to tourism demand shocks. On average, approximately $95 \%$ of the adjustment or more occurs in nearly 5.2 years (Nerlove, 1958, pp. 308-309 \& Nerlove \& Addison, 1958, p. 874).

Overall, the results in this analysis indicate that changes in income and marketing, positively and significantly affect tourist arrivals. Price and transportation cost are also important, suggesting that an increase (decrease) in the values of these variables have a depressing (enhancing) effect in tourism development. The income and price variables, however, have 
greater influence than have the transportation and marketing variables.

With respect to the value of the coefficient of adjustment, the policy implications are very clear. First, expansion of international tourism demand is possible but is not realized immediately. Second, loyalty and/or habit persistence coupled with image/brand name are important considerations in tourists travel decisions. Third, it is not unreasonable to suppose that loyalty and brand name go hand in hand with tourism marketing activities which are reflected in effective commercialization, promotion and advertising campaigns.

\section{Bias due to Omission of Tourism Marketing Variable}

In econometrics, omission of relevant variables correlated with those included, results in biased estimates. The importance of tourism marketing in this analysis is viewed through its effects on coefficients of income and other variables and general model performance. To test the extent of bias due to omission of a tourism marketing variable, unrestricted and restricted equations (tourism marketing variable equal to zero) were estimated. Focusing in the GMM equation, the omission of the tourism marketing variable affected the magnitude of the parameter estimates substantially. Price and transportation cost estimates were reduced by nearly $23 \%$ and $28 \%$, respectively, while income estimates increased by nearly $21 \%$.

In terms of elasticity estimates, the effect of omitting the tourism marketing variable, as evidenced by the drastic change in long and short-run elasticity values for all tourism demand models, emerges more clearly. Moreover, the fit or explanatory power of the GMM, $\mathrm{B}-\mathrm{N}$, and the FMOLS equations dropped. The lagged dependent coefficient increased by nearly $11 \%, 13 \%$ and $14 \%$ respectively. Even though, no test was conducted to assess if they were statistically different from zero.

\section{Substantially Consistent Evidence Found}

The above results have provided, at least, five pieces of relative strong empirical evidence for the twelve countries considered in this study.

(a) There is irrefutably positive and significant link between marketing investment activities and international tourism demand.

(b) Marketing activities have played a significant role in pushing up international inbound tourist arrivals, which is expected to lead to generate more tourism receipts.

(c) The associated bias of the no inclusion of the tourism marketing investment variable is observed and is introduced during the estimation stage.

(d) Omitting the tourism marketing investment variable reduces the fit gained due to its inclusion and bias or render relatively less solid the results that do not include this variable in the analysis. From the reading of the results, in particular related to an almost total neglect of the inclusion of a tourism marketing variable by previous studies leaves their results open to serious questions. In other words, previous international demand studies have shortcomings that, if repaired changes the original results.

(e) Finally, given the above evidence, the only thing that remains to be said is that it felt that the cards deck of previous studies on the international tourism demand were stacked in favor of the income, prices, and other variables

\section{Country Group Pooled Results}

Tables 6, shows the GMM coefficient estimates of the tourism marketing investment variable. All of them have the expected signs confirming a priori expectations. The long-run 
results suggest that a $1 \%$ increase in tourism marketing investment would results in nearly: $0.76 \%$ (inelastic), $1 \%$ (unitary), $0.94 \%$ (inelastic), and $0.84 \%$ (inelastic) increase in tourist arrivals to East Africa, the Caribbean, Central America, and South America from their tourism origin markets, respectively, ceteris paribus. It is confirmed, in the long run, that tourism marketing investment by national tourism institutions has indeed contributed positively towards tourist arrivals in the four-country groups considered in this study.

On the other hand, the short-run marketing elasticity values vary from nearly 0.27 (East Africa), but not significant, to nearly 0.59 (the Caribbean) but significant, with a sample average across regions of nearly 0.46 . These results support the argument about tourism marketing investment's direct and independent importance as a potential factor to enhance international tourism demand for a tourism destination. The Caribbean relatively high elasticity value could be an indication of both its tourism development maturity and its solid tourism marketing campaigns (commercialization, promotion, advertising, public relations, and so on).

The GMM results further confirmed the hypothesis that tourists do not adjust their travel plans instantaneously to changes in income, price, travel cost and marketing but rather adjust to the optimum level in time. The elasticity of adjustment across both country groups and methodologies, on average, is nearly 0.35 for East Africa, nearly 0.59 for the Caribbean, nearly 0.50 for Central America, and nearly 0.60 for South America.

Table 6: Country Group GMM Coefficient Estimates ${ }^{1}$

\begin{tabular}{ccccc}
\hline Variable & OLS Estimates2 & B-N Estimates & FMOLS Estimates & GMM Estimates3 \\
\hline Short-run & & & & \\
\hline LnINC & $1.61^{* * *}$ & $1.32^{* * *}$ & $1.33^{* * *}$ & $1.84^{* * *}$ \\
\hline LnP & $(5.01)$ & $(4.56)$ & $(4.42)$ & $(3.56)$ \\
\hline & $-0.50^{* *}$ & $-0.70^{* * *}$ & $-0.61^{* * *}$ & $-0.82^{* * *}$ \\
\hline LnTC & $(-2.06)$ & $(-4.16)$ & $(-3.09)$ & $(-3.81)$ \\
\hline & $-0.47^{* * *}$ & $-0.75^{* *}$ & $-0.68^{*}$ & $-0.78^{* * *}$ \\
\hline LnMA & $(-4.38)$ & $(-2.11)$ & $(-1.93)$ & $(-3.88)$ \\
\hline & $0.27^{\text {NS }}$ & $0.59^{* * *}$ & $0.47^{* * *}$ & $0.50^{* * *}$ \\
\hline Constant & $(1.46)$ & $(4.93)$ & $(4.14)$ & $(4.63)$ \\
\hline & $-5.74^{* * *}$ & $0.93^{* * *}$ & $-1.61^{* * *}$ & $-2.78^{* * *}$ \\
\hline D1 & $(-10.26)$ & $(8.12)$ & $(-9.02)$ & $(-8.70)$ \\
\hline & $-0.14^{* * *}$ & $-0.31^{* *}$ & -0.19 & $-0.38^{* * *}$ \\
\hline D2 & $(-3.16)$ & $(-1.93)$ & $(-2.03)$ & $(-3.91)$ \\
\hline & $-0.37^{* * *}$ & $-0.38^{* * *}$ & $-0.35^{* * *}$ & $-0.36^{* * *}$ \\
\hline D3 & $(-4.01)$ & $(-3.66)$ & $(-4.60)$ & $(-6.18)$ \\
\hline & $-0.43^{* * *}$ & - & - & - \\
\hline LnTOU & $(-8.66)$ & - & - & - \\
\hline Wald test & $0.6458^{* * *}$ & $0.4116^{* * *}$ & $0.4993^{* * *}$ & $0.4003^{* * *}$ \\
\hline Sargan test & $(9.68)$ & $(5.07)$ & $(4.26)$ & $(6.97)$ \\
\hline Ar1 & 61.32 & 183.49 & 122.74 & 81.17 \\
\hline Ar2 & 0.245 & 0.212 & 0.347 & 0.198 \\
\hline & 0.139 & 0.137 & 0.241 & 0.154 \\
\hline & 0.287 & 0.393 & 0.449 & 0.338 \\
\hline & & &
\end{tabular}




\begin{tabular}{ccccc}
\hline Variable & OLS Estimates2 & B-N Estimates & FMOLS Estimates & GMM Estimates3 \\
\hline Short-run & & & & \\
\hline Long-run & & & & \\
\hline LnINC & 4.55 & 2.24 & 2.66 & -1.07 \\
\hline LnP & -1.42 & -1.19 & -1.22 & -1.38 \\
\hline LnTC & -1.33 & -1.28 & -1.36 & 0.84 \\
\hline LnMA & 0.76 & 1.00 & 0.94 & 3 \\
\hline Countries & 2 & 4 & 3 & 45 \\
\hline Observations & 29 & 79 & 50 & \\
\hline${ }^{1}$ One step results. & & & &
\end{tabular}

For Africa, on average, approximately $95 \%$ of the adjustment or more occurs in nearly 6.85 years. On the other hand, the same $95 \%$ or more of the adjustment occurs in nearly 3.38 years, nearly 4.31 years, and nearly 3.27 years for the Caribbean, Central America, and South America, respectively (Nerlove, 1958, pp. 308-309 \& Nerlove \& Addison, 1958, p. 874). The positive and significant coefficient of the lagged dependent has validated the presence of word-of-mouth effect, repeat tourist arrivals, and tourism supply rigidity, among others.

The dummy variables, representing off-events, were found to be a major deterrent to the international tourism demand for the full panel and for each country group. Both, their significance varies from one country group to another and their inclusion improved the overall estimated results in various cases. The dummy variable D1, accounting for the terrorist attacks showed its negative impact at full sample and at country group level. The dummy variable D2, accounting for the global economic crisis had a relatively stronger negative impact on all regions. The dummy variable D3, accounting for the 2014 West Africa Ebola outbreak, however, had a tremendous impact in East Africa. For example, Tanzania and Kenya started having strong positive results in tourist arrival until 2016, signaling the recovery of the 2014 and 2015 negative results.

From the reported error analysis in Table 7, it can be seen that the estimation results of B-N, FMOLS, and GMM do not differ a great deal. The B-N and FMOLS procedures, however, differ when compared with the GMM procedure in the number of restrictions that are applied. The GMM procedure is built around a multitude of moment conditions of which some will be relevant and others just irrelevant. Therefore, some far off moment conditions can become binding and at the same time severing the downward bias in the GMM and out-weighting the gains in efficiency (Ziliak, 1997).

Table 7: Error Analysis

\begin{tabular}{lccc}
\hline & Balestra and Nerlove $^{1}$ & FMOLS $^{\mathbf{1}}$ & GMM $^{\mathbf{1}}$ \\
\hline East Africa & $0.576-0.331$ & $0.566-0.328$ & $0.408-0.263$ \\
\hline The Caribbean & $0.382-0.306$ & $0.363-0.216$ & $0.347-0.198$ \\
\hline Central America & $0.493-0.326$ & $0.467-0.327$ & $0.483-0.331$ \\
\hline South America & $0.631-0.508$ & $0.616-0.433$ & $0.506-0.371$ \\
\hline
\end{tabular}

${ }^{1}$ First and second column uses one lag length and two lags length, respectively.

At least, three conclusions, however, can be drawn from the error analysis. The first one is that the data do fit the different estimation procedures for the full panel and for the country groups. The second is that, the range of errors varies. For example, in the GMM esti- 
mation, with lag-length of 1 and 2, large errors were in Central America (0.483 and 0.506) and South America (0.506 and 0.371), respectively. On the other hand, in the FMOLS estimation, large errors were in Africa (0.576 and 0.331) and South America (0.631 and 0.508, respectively. The third is that in using the GMM approach, there is a gain in unbiasedness but a relatively amount of efficiency is lost.

\section{Discussion on Policy Implications}

There is a need for the national tourism institutions to have a clear, consistent, and sustained investment policy in tourism marketing activities with respect to enhanced effectiveness in the allocation of financial resources. Moreover, governments and/or tourism institutions finance the bulk of the investment in tourism marketing activities and the demand for public funds is growing over time. Therefore, it is very important to know about the impacts of these vast investments in tourism marketing activities on their international tourism demand.

From the income policy perspective, the relative high-income elasticity values for the full panel and country groups point to a relatively rapid increase in their future market shares in the case of income increases experienced by their origin markets. For these countries, monitoring and evaluating the economic performance of their economies will serve as guidance for successful tourism policy formulation and development. It means matching geographical location, promotion, and management expertise with the market in a way that will attract more tourist arrivals leading to enhanced tourism receipts.

From a price policy perspective, in the long run, a decrease (increase) in these countries' tourism price would lead to a more than proportionate increase (decrease) in the amount of tourist arrivals. Thus, the need for maintaining price competitiveness seems paramount if these countries are to sustain their current growth momentum and future expansion of inbound tourist arrivals. Clearly, policymakers need to keep a keen eye on aggregate of inflation at the national and international levels, and tourism enterprises should be careful with prices in order to maintain the competitive advantage of their tourism products and services.

From the tourism market management perspective, a positive transport policy would be to increase air, land, sea and railways accessibility from their origin markets. However, because to a large extent, tourism is an air transport intensive sector, a national airlift growth strategy for the growth of tourism would enhance both the delivery of tourism products and services and the ability of tourism enterprises to be competitive individually and collectively. In the case of some countries, reducing constraints for the visa processing and issuance regime, as well as borders entry desks is a transport policy in the right direction.

\section{Discussion on Limitations}

There is much more to understanding the tourism marketing activities process of how this works than is, or can be, reported in this study. For example, this study has only examined a portion of the total investment in tourism marketing activities. For policy purposes, it will be nice to have the total investment in tourism marketing activities sorted it out and analyzed in its different components: promotion, commercialization, advertising and so on. During the writing of this analysis, unfortunately, not enough consistent data could be obtained.

As related to the price variable, another limitation is related to the comparison of the results obtained here, versus the results from other studies. While there is much it can be done in the way of adjusting tourism price measures both for obvious theoretical reasons and measurable endogenous influences, it is and will continue to be extremely difficult to devise 
tourism price variables which fully meet the definition of a comprehensive unique tourism price variable. There is no certainty or better no one is certain which of the price definitions is preferable. Therefore, this study is not prepared to defend this set of regression results as superior to the others.

As related to data limitation, in terms of tourism marketing investment, the twelve countries considered in the full sample, with the exception of Barbados (since 1958) and Jamaica (since 1970) which provided a full time-series information for this variable, constitute a most precarious case. The lack of a consistent compilation, tabulation, and publication of the tourism marketing investment data to allow a rigorous analysis of international tourism demand will continue to hamper tourism research and comparisons across countries.

\section{Conclusion}

This study investigated the relative impact of tourism marketing investment on the international tourism demand in the light of the experience of twelve developing countries which are representatives of four country groups or regions. The empirical evidence suggests that there is a positive, direct and independent impact of tourism marketing investment on tourism expansion. Its impact, however, is of a lesser extent than income and price variables. The marketing investment elasticity values suggest that, in the long-run, on average, a $1 \%$ increase in tourism marketing investment results in nearly $0.76 \%, 1.00 \%, 0.94 \%$ and $0.84 \%$ increase in tourist arrivals to East Africa, the Caribbean, Central America, and South America from their tourism origin markets, respectively.

To test the extent of bias, unrestricted and restricted equations were estimated. In terms of elasticity values, the effect of omitting the tourism marketing variable, as evidenced by the drastic change in long and short-run elasticity values for all the international tourism demand models have emerged more clearly.

Covid-19 has completely changed the global economic landscape, severely impacting tourism development worldwide, and bringing it back to the late 1980s early 1990s in terms of both tourist arrivals and tourism foreign exchange earnings. Although there is no way to predict the future and the exact effects this pandemic will have on global tourism development. It is crucial that future, but modified marketing activities with the established health and sanitation entry protocols and other relevant travel and tourism information post Covid-19, connect again with the past and potential tourist arrivals stimulating demand and once again attract tourists.

This study marked significant advances over past research because it has used only official/national data. In terms of tourism marketing investment data availability and quality, for the twelve countries considered in the full sample constitute a most precarious case. Because of this, so far, there is relatively very limited empirical research which has included this important variable. As international tourism demand worldwide has become relatively more competitive, more selective and more sophisticated are sufficient reasons to call for more studies to evaluate the marketing investment impact empirically.

\section{References}

Ahmed, Y.A. (2015). Analytical review of tourism demand studies from 1960 to 2014. International Journal of Science and Research, 4(1), 2421-2427.

AFDB. (2015). Africa tourism monitor: unlocking Africa's tourism potential. Africa Tourism 
Monitor, 3(1-October), Africa Development Bank, New York University.

AFDB. (2018). Africa tourism monitor: The high 5s-Tourism as a pathway to industrialization, integration, quality of life, agriculture, and powering up Africa. Africa Tourism Monitor, 5(1-July), Africa Development Bank, New York University.

Ajaguna, I., Pinnock, F., \& Amode, T.M. (2017). Tourism development and logistics in the Caribbean: Will there be a symbiotic relationship? Worldwide Hospitality and Tourism Themes, 9(1), 116-123.

Association of Caribbean States. (2017). Meetings tourism: Conceptualization and regional vision. Directorate of Sustainable Tourism, Association of Caribbean States.

Arellano, M., \& Bond, S. (1991). Some tests of specification for panel data: Monte Carlo evidence and an application to employment equations, Review of Economic Studies 58, 277-297.

Artus, J.R. (1970). The effects of revaluation on the foreign travel balance of Germany. IMF Staff Papers, 19(3), 602-619.

Balestra, P., \& Nerlove, M. (1966), Pooling cross-section and time-series data in the estimation of a dynamic model: The demand for natural gas, Econometrica34, 585-612.

Baltagi, B.H., \& Levin, D. (1986), Estimating dynamic demand for cigarettes using panel data: The effects of bootlegging, taxation, and advertising reconsidered, Review of Economics and Statistics 68, 148-155.

Baltagi, B.H. (2013), Econometric Analysis of Panel Data. (5th Edition), John Wiley, New York.

Barry, K., \& O'Hagan, J. (1972). An econometric study of British tourist expenditure in Ireland. Economic and Social Review, 3, 143-161.

Bonnett, J. (1982). Implications of marketing and promotion for the development of tourism. Tourism Management, 3(4), 242-247.

Brida, J.G., Cortćs-Jimenez, I., \& Pulina, M. (2016). Has the tourism-led growth hypothesis been validated? A literature review. Current Issues in Tourism, 19(5), 394-430.

Brida, J.G., \& Schubert, S.F. (2008). The economic effects of advertising on tourism demand. Economics Bulletin, 6(45), 1-16.

Brida, J.G., Pereyra, J.S., Such, M.J., \& Zapata, S. (2008). Evaluating the contribution of tourism on economic growth. Anatolia: An International Journal of Tourism and Hospitality Research, 19(2), 351-357.

Buhalis, D. (2000). Marketing the competitive destination of the future. Tourism Management, 21(1), 97-116.

Buhalis, D. (2005). Information and communication technologies for tourism. In Pender, L., and Sharpley, R (Eds). The Management of Tourism, Sage, London, pp. 232-245.

Christie, I., Fernandez, E., Messerli, H., \& Twining-Ward, L. (2014). Tourism in Africa: Harnessing tourism for growth and improved livelihoods. World Bank Report 81468, Washington, DC.

Clarke, C.P. (1978). An analysis of the determinants of demand for tourism in Barbados. Ph.D. dissertation, Fordham University.

Correia, A., \& Kozak, M. (2010). Tourism behavior and marketing: An introduction. Journal of 
Hospitality Marketing and Management, 19(3), 199-202.

Croes, R. (2014). Tourism and poverty reduction in Latin America: Where does the region stand? Worldwide Hospitality and Tourism Themes, 6(3), 293-300.

Croes, R., \& Rivera, M.A. (2017). Tourism's potential to benefit the poor: a SAM model applied to Ecuador. Tourism Economics, 23(1), 29-48.

Croes, R., \& Vanegas, M. (2008). Tourism and poverty alleviation: A co-integration analysis. Journal of Travel Research 47, 94-103.

Croes, R., \& Vanegas, M. (2005). An econometric study of tourist arrivals in Aruba and its implications. Tourism Management, 26, 879-890.

Crouch, G. I. (1994). The study of international tourism demand: a review of findings. Journal of Travel Research, 33(2), 12-23.

Crouch, G.I., Schultz, L., \& Valerio, P. (1992). Marketing international tourism to Australia: a regression analysis. Tourism Management, 13, 196-208.

Crouch, G I., \& Shaw, R. (1991). Determinants of international tourist flows: Findings from 30 years of empirical research. Paper presented at Tourism Research Workshop, September.

Dae-Young, K., Yeong-Hyeon, H., \& Fesenmaier, R. (2005). Modeling tourism advertising effectiveness. Journal of Travel Research, 44(1), 42-49.

Divisekera, S., \& Kulendran, N. (2006). Economic effects of advertising on tourism demand: a case study. Tourism Economics, 12(2), 187-205.

Donohoe, M.H. (2012). Sustainable heritage tourism marketing and Canadas Rideau canal world heritage site. Journal of Sustainable Tourism, 20(1), 121-142.

Doornik, J.A. \& Hendry, D.F. (2001). Econometric Modelling Using PcGive, Volume III. London: Timberlake Consultants Ltd.

Eagle. L., Hamann, M., \& Low, R.D. (2016). The role of social marketing, marine turtles and sustainable tourism in reducing plastic pollution. Marine Pollution Bulletin, 107, 324-332.

Esu, B.B., \& Ebitu, E. (2010). Promoting an emerging tourism destination. Global Journal of Management and Business Research, 21, 21-27.

Fallon, G., \& Schofield, T. (2006). The dynamics of destination attribute importance. Journal of Business Research, 59(6), 709-713.

Fayissa, B., Nsiah, C., \& Tadasse, B. (2011). Tourism and economic growth in Latin American countries: Further empirical evidence. Tourism Economics, 16(6), 1365-1373.

Fayissa, B., Nsiah, C., \& Tadasse, B. (2008). Impact of tourism on economic growth and development in Africa. Tourism Economics, 14(4), 807-818.

Garín-Muñoz, T. (2007). German demand for tourism in Spain. Tourism Management, 28(1), 12-22.

Government of the Republic of Kenya. (2013). Sector plan for tourism 2013-2017. Ministry of East African Affairs, Commerce and Tourism, Nairobi, Kenya.

Hartwell, H., Fyall, A., Willis, C., Page, S., Ladkin, A., \& Hemingway, A. (2018). Progress in tourism and destination wellbeing research. Current Issues in Tourism, 21(16), 1830-1892. 
Hinch. D.T., Higham, S.E.J., \& Moyole, D.B. (2016). Sport tourism and sustainable destinations: foundations and pathways. Journal of Sport and Tourism, 20(3-4), 163-173.

Im, K., Pesaran, M., \& Shin, Y. (2003). Testing for unit roots in heterogeneous panels, Journal of Econometrics, 115, 53-74.

Jamal, T., \& Camargo, A.B. (2014). Sustainable tourism, justice and an ethic of care: Toward the just destination. Journal of Sustainable Tourism, 22(1), 11-30.

Jud, G.D., \& Joseph, H. (1974). International demand for Latin American tourism. Growth and Change, 24-31 (January).

Kibara, O.N., Odhiambo, N.M., \& Njuguma, J.M. (2012). Tourism and economic growth in Kenya: An empirical investigation. International Business and Economics Research Journal, 11(5), 517-528.

Kliman, M.L. (1981). A quantitative analysis of Canadian overseas tourism. Transportation Research, 15A, 487-497.

Kulendran, N., \& Divisekera, S. (2007). Measuring the economic impact of Australian tourism marketing expenditure. Tourism Economics, 13(2), 261-274.

Kulendran, N., \& Dwyer, L. (2009). Measuring the return from Australian tourism marketing expenditure in Asia. JournalofTravelResearch, 47, 275-284. February.

Ledesma-Rodriguez, F.J., Navarro-Ibañez, M., \& Perez-Rodriguez, J.V. (2001). Panel data and tourism: A case study of Tenerife. Tourism Economics, 7, 75-88.

Lim, C. (1997). Review of international tourism demand models. Annals of Tourism Research, 24(4), 835-849.

Liu, S.C., \& Chou, S. (2016). Tourism strategy development and facilitation of integrative processes among brand equity, marketing and motivation. Tourism Management, 54, 298308.

March, R. (1994). Tourism marketing myopia. Tourism Management, 15(6), 411-415.

Martin, C.A., \& Witt, S.F. (1988). Substitute prices in models of tourism demand. Annals of Tourism Research, 15, 255-268.

Mazanec, A. J. (2005). Tourism research in a nutshell: The tourism knowledge map. Tourism Review, 60(3), 6-12.

Nerlove, M. (1958). Distributed lags and demand analysis for agricultural and other commodities. USDA. Agricultural Handbook No. 141, USDA: Washington, DC.

Nerlove, M., \& Addison, W. (1958). Statistical estimation of long-run elasticities of supply and demand. American Journal of Agricultural Economics, 40(4), 861-880.

Nunkoo, R., Ramkissoon, H., \& Gursoy, D. (2013). Use of structural equation modeling in tourism research: past, present, and future. Journal of Travel Research, 52(6), 759-771.

Okello, M., \& Novelli, M. (2014). Tourism in the East African Community: challenges, opportunities, and ways forward. Tourism and Hospitality Research, 14(1-2), 55-60.

Onafowora, O., \& Owowe, O. (2012). Modelling international tourism demand for the Caribbean. Tourism Economics, 18(1), 159-180.

Papadopoulos, S.J., \& Witt, S.F. (1985). A marketing analysis of foreign tourism in Greece. In: S. 
Shaw, L. Sparks and E. Kaynak (eds), Marketing in the 1990s and beyond. Proceedings of the Second World Marketing Congress (University of Stirling), pp. 682-693.

Pedroni, P. (2000). Fully modified OLS for heterogeneous cointegrated panels. Advances in Econometrics, 15, 93-130.

Phillips, P.C.B., \& Hansen, B.E. (1990). Statistical inference in instrumental variables regression with I(1) processes. Review of Economic Studies, 57, 99-125.

Saner, R., Yiu, L., \& Filadoro, M. (2015). Tourism development in Least Developed countries: challenges and opportunities. In Angelo A Camillo (editor). Handbook of Research on Global Hospitality and Tourism Management, IGI Global Publishing, Penn, Chapter 13. pp. 234-261.

Scott, N., Laws, E., \& Boksberger, P. (2009). The marketing of hospitality and leisure experiences. Journal of Hospitality Marketing and Management, 18(2), 99-110.

Seetanah, B. (2010). Assessing the role of marketing promotion in tourism development in a dynamic time series framework. Paper presented at the International Research Symposium in Service Management, Le Meridien Hotel, Mauritius, 24-27 August.

Seetanah, B., Durbarry, R., \& Ragodoo, J.F.N. (2010). Using the panel cointegration approach to analyze the determinants of tourism demand in South Africa. Tourism Economics, 16(3), 715-729.

Seetanah, B., \& Sannassee, R.V. (2015). Marketing promotion financing and tourism development: The case of Mauritius. Journal of Hospitality Marketing and Management, 24(2), 202-215.

Seetanah, B., Sannassee1, R.V., Teeroovengadum, V., \& Nunkoo, R. (2019). Air access liberalization, marketing promotion and tourism development. International Journal of Tourism Research, 21(1), 76-86.

Signé, L., \& Johnson, C. (2018). Africa's tourism potential: Trends, drivers, opportunities and strategies. Africa Growth Initiative Report, Brookings Institution, December.

Song, H., \& Li, G. (2008). Tourism demand modelling and forecasting: A review of recent research. Tourism Management, 29(2), 203-220.

Song, H., Li, G., Witt, S.F., \& Fei, B. (2010). Tourism demand modelling and forecasting: how should demand be measured? Tourism Economics, 16(1), 63-81.

The United Republic of Tanzania. (2002). Tourism master plan: Strategy and actions. CHL Consulting Group, Ministry of Natural Resources and Tourism.

Tourism Research Institute. (2018). Tourism Sector Performance Report 2018. Kenya Tourism Research Institute, Nairobi, Kenya.

UNCTAD. (2017). Economic development in Africa report 2017: Tourism for transformation and inclusive growth. United Nations Conference on Trade and Development, New York and Geneva.

UNCTAD. (2008). The LDCs report 2008: Growth, poverty and the terms of development partnership. United Nations Conference on Trade and Development, New York and Geneva.

UNWTO. (2021). United Nations World Tourism Barometer, 19(1). UNWTO, Madrid, Spain, January. 
UNWTO. (2020). United Nations World Tourism Barometer, 18(1). UNWTO, Madrid, Spain, January.

UNWTO. (2019). International Tourism Highlights. Default Book Series. https://www.e-unwto. org/doi/abs/10.18111/9789284421152

UNWTO. (2015). Tourism in Africa: A tool for development. Affiliate Members Regional Reports, Volume four, United Nations World Tourism Organization, Madrid, Spain.

Uysal, M., \& Crompton, J.L. (1984). Determinants of demand for international tourist flows in Turkey. Tourism Management, 11, 447-475.

Vanegas, M. (2018). An ARDL approach: How robust is Guatemala's international tourism demand? Tourism Review International, 21(2), 121-138.

Vanegas, M., Gartner, W.C., \& Senauer, B. (2015). Tourism and poverty reduction: an economic sector analysis for Costa Rica and Nicaragua. Tourism Economics, 21(1), 159-182.

Vanegas, M. (2014). Aruba's marketing and promotion dynamics: The USA, Venezuela and the Netherlands origin markets. Study No. MV/03/14 prepared for Aruba Tourism Authority as a background paper for consultations on its marketing and promotion policy formulation with Aruba Tourism Authority, the Government and Aruba Hotel and Tourism Association, Oranjestad, Aruba, January-February.

Vanegas, M. (2013a). Co-integration and error correction estimation to forecast tourism in El Salvador. Journal of Travel and Tourism Marketing, 30(6), 523-537.

Vanegas, M. (2013b). Quantification of Aruba's relationships and responses between international tourism demand and marketing spending. Unpublished Background Marketing and Promotion Spending Study No. MV/09/13. Commissioned by Aruba Tourism Authority, Oranjestad, Aruba, December.

Vanegas, M. (2012). Tourism in El Salvador: Cointegration and causality analysis. Tourism Analysis, 17(3), 311-323.

Witt, S.F., \& Martin, C.A. (1987). International tourism demand models-inclusion of marketing variables. Tourism Management, 8, 33-40.

Witt, S.F., \& Witt, C.A. (1995). Forecasting tourism demand: A review of empirical research. International Journal of Forecasting, 11, 447-475.

World Bank (2011). Africa region tourism strategy: Transformation through tourism. World Bank, Washington DC.

World Bank (2010). Kenya's tourism: Polishing the jewel. World Bank Finance and Private Sector Development-African Region, Washington DC.

WTTC. (2020). Travel and tourism: Global economic impact and trends 2020. World Travel and Tourism Council, London, UK.

Ziliak, J. (1997). Efficient estimation with panel data when instruments are pre-determined: An empirical comparison of moment-condition estimation. Journal of Business and Economic Statistics, 15, 419-431. 